\title{
APLIKASI TECHNOLOGY ACCEPTANCE MODEL (TAM) PADA KOMPUTERISASI KEGIATAN PERTANAHAN
}

\author{
Wahyu Prabawati Putri Handayani \& Mugi Harsono \\ Universitas Sebelas Maret Surakarta, Indonesia \\ Email:wahyu.prabawatii@gmail.com
}

\begin{abstract}
Abstrak: Aplikasi Technology Acceptance Model (TAM) Pada Komputerisasi Kegiatan Pertanahan. Tujuan penelitian ini adalah untuk menguji dan menganalisis pengaruh Technology Acceptance Model (TAM) Pada Komputerisasi Kegiatan Pertanahan. Sebuah metodologi survey digunakan untuk mengumpulkan data 100 karyawan. Path analysis menunjukkan bahwa (1) Computer self-efficacy berpengaruh pada persepsi kemudahan penggunaan dan persepsi manfaat teknologi, (2) Persepsi kemudahan penggunaan teknologi berpengaruh pada persepsi manfaat dan sikap untuk menggunakan teknologi, (3) Persepsi manfaat teknologi berpengaruh pada sikap dalam menggunakan teknologi, dan (4) Sikap untuk menggunakan teknologi berpengaruh pada niat untuk menggunakan teknologi.
\end{abstract}

Kata kunci: Technology Acceptance Model (TAM), computer self-efficacy, persepsi manfaat teknologi, sikap menggunakan teknologi, niat menggunakan teknologi

\begin{abstract}
Application of Technology Acceptance Model (TAM) On Computerized Land Activities. The purpose of this study was to examine and analyze the effect of the Technology Acceptance Model (TAM) on computerized land activities. A survey methodology used to collect data of 100 employees. The results indicated that (1) Computer self-efficacy affected the perceived ease of use and usefulness of the technology, (2) the perceived ease of use technology affected of perceived usefulness and attitude towards using technology, (3) the perceived usefulness affected attitude towards using technology, and (4) the attitude to use technology affected intention to use technology.
\end{abstract}

Keywords: Technology Acceptance Model (TAM), computer self-efficacy, perceived usefulness, attitude to use technology, intention to use technology

\section{PENDAHULUAN}

Pelayanan publik berdasarkan Undangundang Republik Indonesia Nomor 25 Tahun 2009 pasal 1 merupakan suatu kegiatan atau rangkaian yang digunakan untuk memenuhi kebutuhan pelayanan atas barang, jasa, dan pelayanan administratif bagi setiap warga negara dan penduduk sesuai dengan peraturan perundang-undangan yang disediakan oleh penyelenggara pelayanan publik. Menurut Peraturan Menteri Pendayagunaan Aparatur Negara dan
Reformasi Birokrasi Republik Indonesia Nomor 16 Tahun 2014, pelayanan publik yang dilakukan oleh aparatur pemerintah saat ini belum memenuhi harapan masyarakat jika dilihat dari berbagai keluhan masyarakat yang disampaikan melalui media masa dan jaringan sosial. Sebagai contoh adalah keluhan layanan masyarakat yang terjadi pada layanan permasalahan pertanahan yang menempati urutan keempat (Suara Ombusdman, 2008). Dampak buruk yang ditimbulkan adalah 
terjadi ketidakpercayaan masyarakat terhadap pelayanan pemerintah. Fenomena ini menyebabkan pemerintah mengeluarkan kebijakan yang menegaskan bahwa pemerintah harus mampu memanfaatkan kemajuan teknologi informasi untuk meningkatkan kemampuan mengolah, mengelola, menyalurkan serta mendistribusikan informasi dan pelayanan publik (Inpres No. 3 Tahun 2003). Langkah utama yang harus diambil dalam menghadapi kemajuan teknologi informasi adalah mempersiapkan pengguna teknologi untuk menerima dan menggunakan teknologi.

Technology Acceptance Model (TAM) merupakan sebuah alat teoritis yang baik (Park, 2009), populer (Priyanka dan Kumar, 2013), dan menawarkan suatu penjelasan yang kuat serta sederhana (Davis, 1989) untuk mempelajari penerimaan dan penggunaan teknologi (Venkatesh, 2000). Technology Acceptance Model (TAM) menunjukkan bahwa terdapat dua keyakinan tertentu, yaitu persepsi kemudahan penggunaan teknologi dan persepsi manfaat teknologi untuk menentukan niat perilaku seseorang dalam menggunakan teknologi (Venkatesh, 2000). Niat merupakan predisposisi perilaku aktual (Ajzen, 1975) yang dipengaruhi oleh computer self efficacy (Venkatesh, 2000; Rose dan Fogarty, 2006; Park, 2009; Yusof et al., 2009; Abramson, 2015), persepsi manfaat dan persepsi kemudahan penggunaan teknologi (Davis, 1989; Davis et al., 1989; Hu et al., 1999; Venkatesh, 2000; Rose dan Fogarty, 2006; Teo et al., 2008; Park, 2009; Yusof et al., 2009; Lin dan Chang, 2011; Suki dan Suki, 2011; Abramson, 2015), serta sikap dalam menggunakan teknologi (Davis et al., 1989; Hu et al., 1999; Rose dan Fogarty, 2006; Teo et al., 2008; Park, 2009; Lin dan Chang, 2011; Suki dan Suki, 2011; Abramson, 2015).

Self efficacy menurut Bandura (1977) merupakan penilaian seseorang terhadap kemampuannya dalam mengorganisasi dan memutuskan tindakan yang diperlukan dengan tujuan untuk mencapai kinerja yang diinginkan. Individu dengan self-efficacy rendah akan merusak motivasi melalui perasaan bahwa mereka tidak mampu untuk menyelesaikan tugas tersebut, sebelum tugas tersebut dicobanya (Davis, 1989). Kajian literatur mengindikasikan bahwa self efficacy berpengaruh pada persepsi manfaat dan persepsi kemudahan penggunaan teknologi. Menurut Rose dan Fogarty (2006) dalam penelitiannya terhadap 208 responden mendapatkan hasil bahwa pengguna teknologi yang memiliki kepercayaan terhadap kemampuannya untuk menggunakan teknologi akan merasa bahwa teknologi tersebut bermanfaat dan mudah untuk digunakan. Hasil penelitian ini mendukung penelitian Park (2009); Venkatesh (2000); Yusof et al. (2009); dan Abramson (2015).

Persepsi manfaat merupakan suatu ukuran di mana penggunaan teknologi dipercaya akan mendatangkan manfaat bagi orang yang menggunakannya, sedangkan persepsi kemudahan terhadap penggunaan teknologi adalah suatu ukuran di mana seseorang yakin bahwa komputer dapat dipahami dan digunakan dengan mudah (Davis, 1989). Kajian literatur mengindikasikan persepsi manfaat akan dipengaruhi oleh persepsi kemudahan penggunaan karena sebuah teknologi yang 
lebih mudah digunakan menjadi lebih berguna (Venkatesh, 2000). Untuk membuktikan pernyataan tersebut telah dilakukan penelitian oleh Teo et al. (2008); Park (2009); Yusof et al. (2009); Lin dan Chang (2011); dan Abramson (2015) dengan hasil mendukung pernyataan yang disampaikan. Kajian literatur juga mengindikasikan bahwa persepsi manfaat teknologi dan persepsi kemudahan penggunaan teknologi berpengaruh pada sikap dalam menggunakan teknologi. Teo et al. (2008) dalam penelitiannya mendapatkan hasil bahwa teknologi dengan persepsi manfaat dan persepsi kemudahan penggunaan teknologi yang tinggi akan membentuk sikap positif dalam penggunaannya karena sikap merupakan prediksi untuk menggunakan sebuah teknologi. Hasil penelitian ini mendukung penelitian Hu et al. (1999); Park (2009); Lin dan Chang (2011); dan Abramson (2015).

Sikap merupakan suatu disposisi untuk merespon secara positif atau negatif suatu perilaku. Secara umum, semakin individu memiliki evaluasi bahwa suatu perilaku akan menghasilkan konsekuensi positif maka individu akan cenderung bersikap baik terhadap perilaku tersebut, sebaliknya semakin individu memiliki evaluasi negatif maka individu akan cenderung bersikap tidak baik terhadap perilaku tersebut (Ajzen, 2005). Hubungan antara sikap dalam menggunakan teknologi dengan niat untuk menggunakan teknologi telah banyak diteliti sebelumnya. Penelitian $\mathrm{Hu}$ et al. (1999) terhadap dokter di Hongkong mendapatkan hasil bahwa sikap berpengaruh signifikan terhadap niat untuk menggunakan teknologi, hal ini berarti bahwa sikap dalam menggunakan teknologi memprediksi niat untuk menggunakan teknologi. Hasil penelitian ini sejalan dengan penelitian Park (2009); Lin dan Chang (2011); Suki dan Suki (2011); dan Abramson (2015).

Berdasarkan uraian diatas yang didasarkan pada penelitian terdahulu, maka penelitian ini bertujuan untuk menguji dan menganalisis pengaruh variabel yang membangun Technology Acceptance Model (TAM). Penelitian ini akan dilakukan pada Kementerian Agraria dan Tata Ruang/Badan Pertanahan Nasional Kantor Pertanahan Kabupaten Sukoharjo yang diaplikasikan pada layanan Komputerisasi Kegiatan Pertanahan. Aplikasi ini diharapkan dapat menjadi titik awal bagi terwujudnya inovasi layanan berbasis teknologi informasi dan komunikasi untuk menunjang performansi kinerja pelayanan pengaturan dan penataan pertanahan serta menyelesaikan masalah agrarian (Surat Edaran Nomor 5/SE100/I/2015).

\section{METODE}

Penelitian ini dikategorikan sebagai penelitian survey. Penelitian ini dilaksanakan di Kementerian Agraria dan Tata Ruang/Badan Pertanahan Nasional Kantor Pertanahan Kabupaten Sukoharjo. Variabel yang digunakan dalam penelitian ini adalah computer self efficacy, persepsi kemudahan penggunaan teknologi, persepsi manfaat teknologi, sikap untuk menggunakan teknologi, dan niat dalam menggunakan teknologi. Kerangka pemikiran dalam penelitian ini tertuang dalam Gambar 1.

Berdasarkan dugaan sementara bahwa computer self efficacy berpengaruh pada persepsi manfaat teknologi (Rose dan 


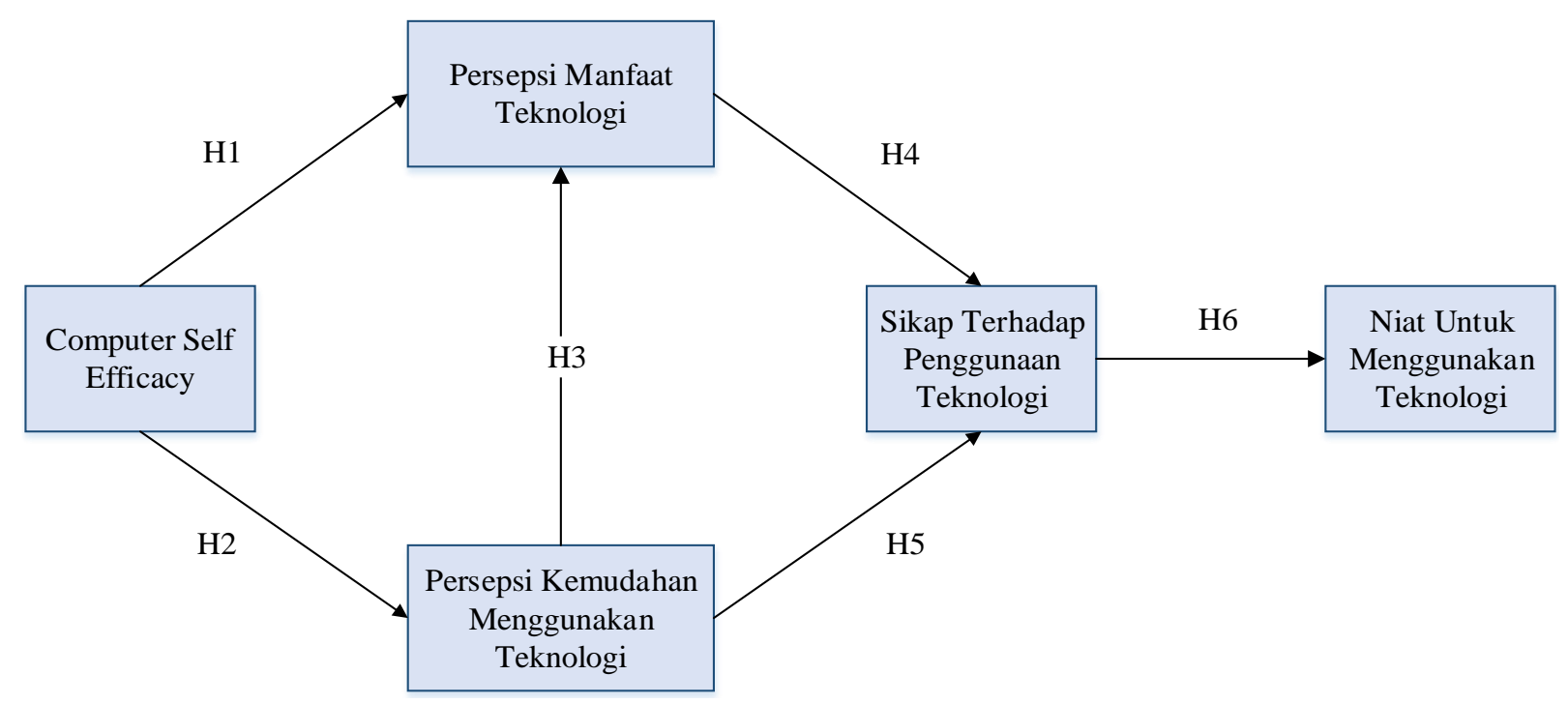

Gambar 1. Skema Konseptual Penelitian (Davis et al., 1989; Park, 2009)

Fogarty, 2006; dan Park, 2009), dan persepsi kemudahan penggunaan teknologi (Venkatesh, 2000; Rose dan Fogarty, 2006; Park, 2009; Yusof et al., 2009; dan Abramson, 2015). Persepsi kemudahan penggunaan teknologi berpengaruh pada persepsi manfaat teknologi (Teo et al., 2008; Park, 2009; Yusof et al., 2009; Lin dan Chang, 2011, dan Abramson, 2015). Persepsi manfaat teknologi dan persepsi kemudahan penggunaan teknologi berpengaruh pada sikap untuk menggunakan teknologi (Teo et al., 2008; Park, 2009; Lin dan Chang, 2011; dan Abramson, 2015). Sikap berpengaruh pada niat untuk menggunakan teknologi ( $\mathrm{Hu}$ et al., 1999; Park, 2009; Lin dan Chang, 2011; Suki dan Suki, 2011; dan Abramson, 2015), maka hipotesis yang diajukan dalam penelitian ini adalah sebagai berikut:

H1: Computer self efficacy berpengaruh pada persepsi manfaat teknologi

$\mathrm{H} 2$ : $\quad$ Computer self efficacy berpengaruh pada persepsi kemudahan penggunaan teknologi
H3: Persepsi kemudahan penggunaan teknologi berpengaruh pada persepsi manfaat

H4: Persepsi manfaat berpengaruh pada sikap untuk menggunakan teknologi

H5: Persepsi kemudahan penggunaan teknologi berpengaruh pada sikap

H6: Sikap berpengaruh pada niat untuk menggunakan teknologi

Sampel merupakan bagian dari jumlah dan karakteristik yang dimiliki oleh populasi (Sugiyono, 2010). Ukuran sampel yang digunakan menggunakan indikator 20 observasi per variabel (Dachlan, 2014), maka sampel adalah minimal 100 orang. Teknik penarikan sampel dalam penelitian ini menggunakan teknik purposive sampling, yaitu seseorang diambil sebagai sampel karena dipastikan bahwa seseorang tersebut memiliki informasi yang diperlukan bagi penelitian (Sugiyono, 2010). Kriteria dalam purposive sampling yang dimaksud, adalah (1) responden merupakan Pegawai Negeri Sipil Kementerian Agraria dan Tata Ruang/Badan Pertanahan Nasional Kantor 
Pertanahan Kabupaten Sukoharjo dan (2) responden memiliki fasilitas akses internet untuk aplikasi Komputerisasi Kegiatan Pertanahan.

Instrumen penelitian untuk pengumpulan data dalam penelitian ini menggunakan kuesioner. Uji instrumen penelitian meliputi uji validitas dan uji reliabilitas. Uji validitas menggunakan teknik Confirmatory Factor Analysis (CFA) dengan bantuan AMOS 22. Standar loading estimate yang digunakan pada masing-masing item pertanyaan dalam penelitian ini adalah $\geq$ 0,50 (Ghozali, 2008). Uji reliabilitas menggunakan Cronbach alpha sebesar 0,7 (Ghozali, 2008). Teknik analisis data menggunakan path analysis yang merupakan pengembangan dari model regresi yang digunakan untuk menguji kesesuaian (fit) dari matrik korelasi dua atau lebih suatu model yang dibandingkan (Ghozali, 2008). Kelebihan analisis jalur adalah dalam hal kemampuannya untuk menentukan tipe relasi antar variabel independen dan ketika menjelaskan hubungannya dengan variabel dependen (Dachlan, 2014). Indeks kesesuaian model Goodness of fit yang digunakan dalam penelitian ini menggunakan referensi dari Ferdinand (2006).

\section{HASIL DAN PEMBAHASAN}

Penelitian ini menggunakan path analysis dengan bantuan program AMOS 22. Hal-hal yang diperhatikan dalam melakukan pengujian dengan pendekatan path analysis yaitu asumsi model, analisis kesesuaian model dan analisis koefisien jalur.

\section{Asumsi Model}

Penelitian ini menggunakan uji normalitas untuk mengetahui apakah data berdistribusi normal ataukah tidak. Evaluasi normalitas diidentifikasi baik secara univariate maupun multivariate. Secara univariate untuk nilainilai dalam C.r skewness, tidak terdapat item pernyataan yang menunjukkan nilai $>2,58$. Sedangkan untuk nilai-nilai dalam C.r kurtosis, semua item pernyataan menunjukkan nilai $<2,58$. Dengan demikian analisis selanjutnya dapat dilakukan.

Penelitian ini juga menggunakan uji terhadap multivariate outliers dengan menggunakan kriteria jarak mahalanobis pada tingkat $p<0,001$. Jarak mahalanobis itu dievaluasi dengan menggunakan $\chi^{2}$ pada derajat bebas sebesar jumlah variabel indikator yang digunakan dalam penelitian (Ferdinand, 2006). Penelitian ini menggunakan 5 variabel indikator, sehingga semua kasus yang mempunyai Jarak Mahalanobis lebih besar dari $\chi^{2}(5 ; 0,001)=$ 20,515 adalah multivariate outlier. Hasil menunjukkan bahwa tidak ditemukan adanya kasus yang dapat dikategorikan sebagai outlier karena semua observasi memiliki jarak mahalanobis $<20,515$.

\section{Analisis Kesesuaian Model}

Dalam pengujian ini nilai $\chi^{2}$ menghasilkan tingkat signifikansi lebih besar dari 0,05 dengan nilai $\chi^{2}$ sebesar 6,521 menunjukkan bahwa model penelitian yang diajukan sudah memenuhi. Nilai CMIN/DF, GFI, AGFI, TLI, CFI, dan RMSEA dalam model penelitian ini menunjukkan tingkat kesesuaian yang baik. 
Tabel 1. Hasil Goodness-of-Fit Model

\begin{tabular}{llll}
\hline \multicolumn{1}{c}{ Goodness-of-fit Indices } & \multicolumn{1}{c}{ Cut-off Value } & Hasil & Evaluasi Model \\
\hline Chi-Square $\left(\chi^{2}\right)$ & Diharapkan kecil & 6,521 & Fit \\
Degrees offreedom & Positif & 4 & Fit \\
Probability level $(p)$ & $\geq 0,05$ & 0,164 & Fit \\
CMIN/DF & $\leq 2,0$ & 1,630 & Fit \\
GFI & $\geq 0,90$ & 0,975 & Fit \\
AGFI & $\geq 0,90$ & 0,907 & Fit \\
TLI & $\geq 0,95$ & 0,962 & Fit \\
CFI & $\geq 0,95$ & 0,985 & Fit \\
RMSEA & $\leq 0,08$ & 0,080 & Fit \\
\hline
\end{tabular}

\section{Analisis Koefisien Jalur}

Hasil pengujian menunjukkan bahwa dari 6 jalur yang dianalisis, semua memiliki hubungan yang signifikan, terlihat dari besarnya tingkat signifikansi (p) uji hipotesis kurang dari $5 \%$.

Hasil analisis jalur menunjukkan nilai CR computer self efficacy pada persepsi manfaat teknologi sebesar 2,758 dengan tingkat signifikansi 0,006 . Nilai $p<0,05(0,006<$ 0,05), maka dapat disimpulkan bahwa computer self efficacy berpengaruh pada persepsi manfaat teknologi sehingga hipotesis 1 didukung dalam penelitian ini. Fenomena ini dapat terjadi karena karyawan memiliki keyakinan tinggi bahwa penggunaan Komputerisasi Kegiatan
Pertanahan akan memberikan manfaat untuk penyelesaian pekerjaan mereka sehingga karyawan dapat mencapai kinerja yang diinginkan. Hasil penelitian ini mendukung penelitian yang dilakukan oleh Rose dan Fogarty (2006) dan Park (2009) yang menunjukkan bahwa computer self efficacy menentukan persepsi manfaat. Park (2009) juga mengemukakan bahwa bahwa computer self efficacy merupakan konstruk yang baik pada Technology Acceptance Model.

Nilai CR computer self efficacy pada persepsi kemudahan menggunakan teknologi sebesar 5,855 dengan tingkat signifikansi 0,000 . Nilai $p<0,05(0,000<$ 0,05), maka dapat disimpulkan bahwa

Tabel 2. Regression Weights

\begin{tabular}{|c|c|c|c|c|c|c|}
\hline & & & Estimate & S.E. & C.R. & $\mathrm{P}$ \\
\hline $\begin{array}{l}\text { Persepsi } \\
\text { kemudahan }\end{array}$ & $<---$ & $\begin{array}{l}\text { Computer Self } \\
\text { Efficacy }\end{array}$ & .549 & .094 & 5.855 & $* * *$ \\
\hline $\begin{array}{l}\text { Persepsi } \\
\text { Manfaat }\end{array}$ & $<--$ & $\begin{array}{l}\text { Computer Self } \\
\text { Efficacy }\end{array}$ & .260 & .094 & 2.758 & .006 \\
\hline $\begin{array}{l}\text { Persepsi } \\
\text { Manfaat }\end{array}$ & $<---$ & $\begin{array}{l}\text { Persepsi } \\
\text { kemudahan }\end{array}$ & .383 & .087 & 4.407 & $* * *$ \\
\hline Sikap & $<---$ & $\begin{array}{l}\text { Persepsi } \\
\text { Manfaat }\end{array}$ & .285 & .097 & 2.934 & .003 \\
\hline Sikap & $<---$ & $\begin{array}{l}\text { Persepsi } \\
\text { kemudahan }\end{array}$ & .475 & .090 & 5.297 & $* * *$ \\
\hline Niat & $<---$ & Sikap & .626 & .088 & 7.122 & $* * *$ \\
\hline
\end{tabular}


computer self efficacy berpengaruh pada persepsi kemudahan penggunaan teknologi, sehingga hipotesis $\mathbf{2}$ didukung dalam penelitian ini. Fenomena ini dapat terjadi karena karyawan memiliki keyakinan tinggi terhadap kemampuan dan keterampilannya dalam menggunakan aplikasi Komputerisasi Kegiatan Pertanahan, oleh karena itu mereka merasa mudah dalam menggunakan aplikasi tersebut tanpa memerlukan usaha yang besar. Hasil penelitian ini mendukung penelitian yang dilakukan oleh Venkatesh (2000); Rose dan Fogarty (2006); Park (2009); Yusof et al. (2009); dan Abramson (2015) yang menemukan bahwa Computer self efficacy berpengaruh terhadap persepsi kemudahan penggunaan teknologi.

Hasil analisis jalur juga menunjukkan nilai $\mathrm{CR}$ persepsi kemudahan penggunaan teknologi pada persepsi manfaat teknologi sebesar 4,407 dengan tingkat signifikansi 0,000 . Nilai $p<0,05(0,000<0,05)$, maka dapat disimpulkan bahwa persepsi kemudahan penggunaan teknologi berpengaruh pada persepsi manfaat teknologi, oleh karena itu hipotesis 3 didukung dalam penelitian ini. Fenomena ini dapat terjadi karena karyawan yang merasa mudah dalam menggunakan aplikasi Komputerisasi Kegiatan Pertanahan akan merasakan manfaat yang diperoleh dari adanya teknologi tersebut untuk penyelesaian pekerjaan mereka. Hasil penelitian ini mendukung penelitian yang dilakukan oleh Teo et al. (2008); Park (2009); Yusof et al. (2009); Lin dan Chang (2011), dan Abramson (2015) yang menemukan bahwa Persepsi kemudahan berpengaruh terhadap persepsi manfaat.
Nilai CR persepsi manfaat teknologi pada sikap untuk menggunakan teknologi sebesar 2,934 dengan tingkat signifikansi 0,003 . Nilai $p<0,05(0,003<0,05)$, maka dapat disimpulkan bahwa persepsi manfaat teknologi berpengaruh terhadap sikap untuk menggunakan teknologi, sehingga hipotesis 4 didukung dalam penelitian ini. Fenomena ini dapat terjadi karena apabila karyawan merasa bahwa aplikasi Komputerisasi Kegiatan Pertanahan memiliki banyak manfaat untuk menyelesaikan pekerjaan mereka maka akan mempengaruhi sikap karyawan untuk menggunakan teknologi tersebut. Hasil penelitian ini mendukung penelitian yang dilakukan oleh $\mathrm{Hu}$ et al. (1999); Teo et al. (2008); Park (2009): Lin dan Chang (2011); dan Abramson (2015), yang menemukan bahwa persepsi manfaat berpengaruh terhadap sikap dalam menggunakan teknologi.

Hasil analisis jalur menunjukkan nilai CR persepsi kemudahan penggunaan teknologi pada sikap dalam menggunakan teknologi sebesar 5,297 dengan tingkat signifikansi 0,000 . Nilai $p<0,05(0,000<0,05)$, maka dapat disimpulkan bahwa persepsi kemudahan penggunaan teknologi berpengaruh terhadap sikap dalam menggunakan teknologi, sehingga hipotesis 5 didukung dalam penelitian ini. Fenomena ini dapat terjadi karena karyawan yang merasa mudah dalam menggunakan aplikasi Komputerisasi Kegiatan Pertanahan akan menentukan sikap untuk menerima atau menolak menggunakan teknologi dalam penyelesaian pekerjaannya. Hasil penelitian ini mendukung penelitian Teo et al. (2008); Park (2009); Lin dan Chang (2011); dan Abramson (2015) yang menemukan bahwa 
Persepsi kemudahan penggunaan teknologi berpengaruh terhadap sikap dalam menggunakan teknologi.

Hasil analisis jalur juga menunjukkan nilai CR sikap dalam menggunakan teknologi terhadap niat untuk menggunakan teknologi sebesar 7,122 dengan tingkat signifikansi 0,000 . Nilai $p<0,05(0,000<0,05)$, maka dapat disimpulkan bahwa sikap dalam menggunakan teknologi berpengaruh terhadap niat untuk menggunakan teknologi, sehingga hipotesis 6 didukung dalam penelitian ini. Fenomena ini dapat terjadi karena karyawan yang memiliki sikap untuk menerima atau menolak dalam menggunakan teknologi akan mempengaruhi niatnya untuk menggunakan teknologi tersebut dalam menyelesaikan pekerjaannya. Jika karyawan memiliki sikap untuk menolak menggunakan teknologi, maka karyawan tidak berniat untuk menggunakan teknologi tersebut. Akan tetapi, jika karyawan memiliki sikap untuk menerima teknologi, maka karyawan tersebut memiliki niat yang kuat untuk terus menggunakan teknologi dalam menyelesaikan pekerjaannya. Hasil penelitian ini mendukung penelitian yang dilakukan oleh Hu et al. (1999); Park (2009); Lin dan Chang (2011); Suki dan Suki (2011); Abramson (2015) yang menemukan bahwa sikap berpengaruh terhadap niat untuk menggunakan teknologi.

\section{SIMPULAN}

Hasil penelitian mengenai aplikasi Technology Acceptance Model (TAM) Pada Komputerisasi Kegiatan Pertanahan di Kementerian Agraria dan Tata Ruang/Badan Pertanahan Nasional Kantor Pertanahan
Kabupaten Sukoharjo dapat diambil kesimpulan, sebagai berikut:

1. Computer self efficacy berpengaruh pada persepsi manfaat karyawan.

2. Computer self efficacy berpengaruh pada persepsi kemudahan penggunaan teknologi.

3. Persepsi kemudahan teknologi berpengaruh pada persepsi manfaat.

4. Persepsi manfaat berpengaruh pada sikap dalam menggunakan teknologi.

5. Persepsi kemudahan penggunaan teknologi berpengaruh pada sikap dalam menggunakan teknologi.

6. Sikap dalam menggunakan teknologi berpengaruh pada niat perilaku untuk menggunakan teknologi.

\section{DAFTAR PUSTAKA}

Abramson, J., Dawson, M., Stevens, J. (2015). An Examination of the Prior Use of ELearning Within an Extended Technology Acceptance Model and the Factors That Influence the Behavioral Intention of Users to Use M-Learning. Sage Open, hal. 1-9.

Ajzen, I. (2005). Attitude, Personality and Behavior. New York: Open University Press

Bandura, A. (1977). Self-Efficacy: Toward A Unifying Theory of Behavioral Change. Psychological Review, 84(2), 191-215.

Dachlan, U. (2014). Panduan lengkap Structural Equation Modeling Tingkat Dasar. Semarang: Lentera IImu.

Davis, F.D. (1989). Perceived Usefulness, Perceived Ease Of Use And User Acceptance Of Information Technology. MIS Quarterly, 13(3), 319-340.

Davis, F.D., Bagozzi, R.P., \& Warshaw, P.R. (1989). User Acceptance Of Computer 
Technology: A Comparison of Two Theoretical Models. Management Science, 35(8), 982-1003.

Ferdinand, A. (2006). Structural Equation Modeling Dalam Penelitian Manajemen. Semarang: Badan Penerbit Universitas Diponegoro.

Fishbein, M. and Ajzen, I. (1975), Belief, Attitude, Intention and Behavior: An Introduction to Theory and Research, Addison-Wesley, Reading, MA.

Ghozali, I. (2008). Model Persamaan Struktural Konsep dan Aplikasi Dengan Program Amos 16.0. Semarang: Badan Penerbit Universitas Diponegoro.

Hu, P.J., Chau, P.Y.K., Sheng, O.R.L, Tam, K.Y. (1999). Examining the Technology Acceptance Model Using Physician Acceptance of Telemedicine Technology. Journal of Management information Systems, 16(2), 91-112.

Instruksi Presiden Republik Indonesia Nomor 3 Tahun 2003 Tentang Kebijakan Dan Strategi Nasional Pengembangan EGovernment.

Lin, J dan Chang, H. (2011). The Role Of Technology Readiness In Self-Service Technology Acceptance. Managing Service Quality: An International Journal, 21(4), $424-444$.

Park, S.Y. (2009). An Analysis of the Technology Acceptance Model In Understanding University Students Behavioral Intention to Use e-Learning. Educational Technology \& Society, 12(3), 150-162.

Peraturan Menteri Pendayagunaan Aparatur Negara dan Reformasi Birokrasi Nomor 16 Tahun 2014 Tentang Pedoman Survei Kepuasan Masyarakat Terhadap Penyelenggaraan pelayanan Publik.

Priyanka, S dan Kumar, A. (2013). Understanding The Evolution of Technology Acceptance Model.
International Journal of Advance Research in Computer Science and Management Studies, 1(6), 144-148.

Rose, J dan Fogarty, G. (2006). Determinants Of Perceived Usefulness and Perceived Ease Of Use In The Technology Acceptance Model: Senior Consumers Adoption Of Self-Servive Banking Technologies. Academy of World Business, Marketing \& Management Development, 2(10), 122-129.

Suara Ombudsman. (2008). Kerjasama Komisi Ombudsman Nasional dan Badan Pertanahan Nasional dalam rangka Peningkatan Kualitas Penanganan Keluhan Bidang Pertanahan. Artikel. ISSN: $1412-3932$.

Sugiyono. (2010). Metode Penelitian Bisnis. Bandung: Alfabeta.

Suki, N.M dan Suki, N.M. (2011). Exploring The Relationship Between Perceived Usefulness, Perceived Easy Of Use, Perceived Enjoyment, Attitude And Subscribers Intention Towards Using 3G Mobile Services. Journal of Information Technology Management, 22(1), 1-7.

Surat Edaran Nomor 5/SE-100/1/2015 Tentang Penggunaan Aplikasi Komputerisasi Kegiatan Pertanahan

Teo, T., Luan, W.S., Sing, C. C. (2008). A CrossCultural Examination Of The Intention To Use Technology Between Singaporean and Malaysian Pre-Service Teachers: An Application Of The Technology Acceptance Model (TAM). Educational Technology \& Society, 11(4), 265-280.

Undang-undang Republik Indonesia Nomor 25 Tahun 2009 Tentang Pelayanan Publik.

Venkatesh, V. (2000). Determinants of Perceived Ease of Use: Integrating Control, Intrinsic Motivation, and Emotion into the Technology Acceptance Model. Information System Research, 11(4), 342-365. 
Jurnal Economia, Volume 12, Nomor 1, April 2016

Yusoff, Y.M., Muhammad, Z., Pasah, E.S.E., Robert, E. (2009). Individual Differences, Perceived Ease of Use, and Perceived
Usefulness in the E-Library Usage. Computer and Information Science, Vol. 2(1), 76-83. 